\title{
Parental Perceptions of Early Childhood English Education
}

\author{
Lin, Ching-Ying ${ }^{1}$, Chen, Hsiang-Chun ${ }^{2}$
}

Department of Applied English, National Pingtung University, Taiwan, R.O.C

\begin{abstract}
This study aims to explore general parental perceptions of early childhood English education in kindergartens, and to probe the significant differences parental perceptions of English learning between public and bilingual kindergartens. In addition, the study also intends to discover parental opinions about the advantages and disadvantages for children to attend early childhood English education, and parental supported for their children learning English. The subjects involved of this study were 200 parents whose children were studying in kindergartens. They were required to complete questionnaires. Twenty of parents were invited to attend the following individual interviews. The results illustrated most parents agreed that infancy is the important period for English learning and development. Both bilingual and public kindergarten students' parents emphasized that the learning environment influences the English development of their young children, and qualified English teachers should pass the general English proficiency test. The parents from Bilingual kindergarten underlined that early childhood English education didn't affect Chinese learning of their children. Most parents agreed their children can get better jobs in the future by taking early childhood English education. Bilingual kindergarten parents would provide English Nursery Rhymes CDs, English cartoon, read English storybooks, and English teaching DVD for their children's English learning. But most Public Kindergarten parents didn't.
\end{abstract}

Keywords: Early childhood English education, English Learning, Parental Attitudes, Parents' Perceptions, Bilingual Kindergarten.

\section{INTRODUCTION}

Gardner (1985) pointed out that parental attitudes take an important part in their children's second language learning. Most parents believe the perfect timing for young children to learn English should be as early as possible. It is generally agreed that children have amazing abilities to learn languages. Lenneberg (1969) illustrated that children could acquire better success in early childhood language learning. Alhussein and Milian (2003) also indicated that children can learn a second language successfully at the same time when they are learning the first language, or after they achieve their first language. In fact, most Taiwanese could speak Chinese, Hakka or Taiwanese in a highly complex language environment since they were children. Alhussein and Milian (2003) and Mushi (2001) clarified that children's brains expand new synaptic connections to supply structures of different languages learning at the same time. Many Taiwanese parents had language learning experiences, so they believe their children can learn many kind of language at the same time.

Nowadays, English has became one of the major second foreign language in Taiwan.

But English learning have some limits on learning environment and Taiwanese unique character. Most Taiwanese feel shy and afraid to speak English in social environment. Thus, Taiwanese parents hoped their children could speak English like native speakers. So, Taiwanese parents choose bilingual kindergartens for children to receive early childhood English education in order to get better English abilities (Tavil. 2009; Lao. 2004). Shannon and Milian (2002) indicated that early childhood English education can help young children learn better English communication skills, and help them show more confidence than the others (Na, 2016; Roopnarine, Shin, Donovan, \& Suppal, 2000).

$\mathrm{Na}$, (2016) emphasized most young children who have received early childhood English education in bilingual kindergartens show greater English abilities and speak fluently English like native speakers. Lao (2004), Liu \& Chien (1998), and Oladejo (2006) designated that Taiwanese Parents have greater confidence in the success of children's English learning and children's better career opportunities in the future by attending early childhood English education in bilingual kindergartens (Shang, Ingebritson \& Tseng 2007, Romero- gonzalez 2008). 
However, students seldom communicate with foreigners or speak English during their free time, so they can't speak English frequently although they have received early childhood English education. Moreover, some studies still doubted the effective of bilingual learning program in kindergartens. The most argument were about the qualification of English teachers (Chang, 2004; Na, 2016; Tsai, 2003; Shang, Ingebritson, \& Tseng, 2007; Wu, 1998). According to previous studies, most parents believed foreign teachers have better qualification to teach English than Chinese English teachers.

Furthermore, Taiwan government has considered the need of English learning. The English education policy has been change children's better English learning timing several time (Butler, 2004). Parental attitudes and the improvement in English education influenced the implementation of the English education policy (Chang, 2008). Chang (2008) investigated the effectiveness of Taiwanese Ministry of Education (MOE) implemented the new English education policy these years, and found out English education policy came across some problems, such as the qualification of English Teachers, the employment of English Teachers, the best timing for children to start English learning ..etc. She also found out that new English education policy mismatched parental expectation.

In this study, parental general perceptions toward early childhood English education, and the significant differences in parental attitudes toward early childhood English learning between public and bilingual kindergartens, were indicated. The research questions were based on the purpose of the study as follows: 1.) What are parental general attitudes toward early childhood English education in kindergartens? 2.) What are the significant differences in parental attitudes toward early childhood English learning between public and bilingual kindergartens? 3.) In parental opinions, what are the advantages and disadvantages for children to attend early childhood English education? 4.) How do parents support their children learning English?

\section{LITERATURE REVIEW}

\subsection{Parents Attitudes toward English Education}

Parental attitudes are important as they also give an active influence on their children's language learning. Parents exert all their powers on their children's education (Young, 1994), such like help children with their homework and promote children's second language learning. Language learning is a unavoidable procedure in Taiwanese education. Most parents keep positive attitudes toward early childhood English education (Barbara, 1996). They provide variety ways to support their children's English learning and contract friendship with teachers. Most parents believe that their children attending language learning at early childhood, can gain more effective achievement ( $\mathrm{Na}, 2016)$. Cotton and Wikelund (1989) investicated that parental support on their children's early English education show remarkable results and more powerful effects on the early period. In addition, positive parental attitudes can help children resist the tough English learning (Gardner, 1985).

However, parental attitudes can have both positive and negative effects on the early childhood English education. Rosenbuch (1987) pointed out that parents who maintain positive parental attitudes toward second language learning work upon their children's second language learning all the time, and encourage children to practice the second language at home. Lee \& Ginsburg (2009) exhibited that lots of parents believe that bilingual schools can assist children's development of English communication ability, and support the achievements of bilingual education ( $\mathrm{Na}, 2016)$. In addition, parents believe the early childhood English education can enhance children overall learning and communicative competence (Lao, 2004; Cava, 1998). Moreover, parents believe their children can increase their self-image and confidence by learning a foreign language.

\subsection{The Affection of Early Childhood English Education}

Chang (2008) designated that English is one of the important language in the globalization world. Nowadays, English is also the first choice of most parents on second language learning (Chang, 2008; Oladejo's, 2006). English learning become an essential process of school's curriculum in Taiwan. Furthermore, children have more pleasure to take Early childhood English education in the kindergartens. Children imitated their English teachers' pronunciation during learning, and showed better English accents and less anxiety on English learning (Finney, Protopapas \& Eimas, 1996; Tavil, 2009). Tsau \& Hao (2010) claimed that most students started English learning in kindergartens, but different English learning ways also influenced students' motivation. 
Recently, early childhood English education has become disputable issue in China (Na, 2016). The main reasons of parents' positive attitudes toward Early childhood English education were they believed children could increase English communicative competence, self-confidence, and get better career in the future (Cava, 1998; Lao, 2004; Lee \& Ginsburg 2009; Griva, \& Chouvarda, 2012; Saucedo, 1997; Shannon \& Milian, 2002; Shang, Ingebritson, \& Tseng, 2007; Tseng, 2007). In addition,Tsai (2001) explored parental purpose toward bilingual programs of the kindergartens were the beliefs that children can gain better job in the future (Lao, 2004; Lindholm-Leary \& Borsato, 2002; Shannon \& Milian, 2002; Shin, 2000; Shang, Ingebritson, \& Tseng, 2007; Young \& Tran, 1999). These parents also believed children were able to improve English four skills by attended early childhood English education and become more intelligent than before.

\section{Methodology}

\subsection{Subjects}

The subjects involved in this study were 200 parents whose children were studying in kindergartens in Pingtung. 100 parents whose children were studying in bilingual kindergartens and 100 parents whose children were studying in public kindergartens. Twenty parents of them were invited to attend the following individual interviews. Ten of parents were from public kindergartens, and the others were from bilingual kindergartens.

\subsection{Instruments}

The instruments of the present study were a questionnaire and individual interviews. First, there were 40 items on the questionnaire. The questionnaire was designed for parents whose children were studying in public or in bilingual kindergartens, and divided into three parts to ask these parents about their attitudes toward early childhood English education.

The first part was to ask the personal data of parents. The second part was involved 40 items and divided into five section, the questions of first section were to ask parents' general attitudes about how important, and effective for young children to attend early childhood English education. The second section's questions were to ask these parents about the setting of English learning in bilingual kindergartens. The third section was to ask the influence of early childhood English education. The fourth section was to ask how parents support for their children's English learning. The fifth section was to ask the benefit of early childhood English learning and parental opinions toward the administration of new early childhood English education policy.

These items were designed in a five-point Likert scale, , ranging from ( $\mathrm{SA}=$ strongly agree, $\mathrm{A}=$ agree, $\mathrm{UN}=$ unsure, $\mathrm{D}=$ disagree, $\mathrm{SD}=$ strongly disagree). Finally, at the third part was to explore participants' advices for this questionnaire. The questionnaires were given personally to the parents in the kindergartens by the researcher. One hundred questionnaires were given to bilingual kindergartens' parents and One hundred questionnaires were given to public kindergartens' parents.

Secondly, for the interviews, each interview was used a digital voice-recording pen to record parents' responses and lasted for about 30 to 45 minutes. Then the researcher translated these responses into English. The questions of the interviews were involved as below: (1). Why do you choose to take your children to study in this public (bilingual) kindergarten? (2). In parental opinions, what are the advantages and disadvantages for children to receive early childhood English education? (3). In parental opinions, how does early childhood English education affect children's Chinese learning? (4). How do parents support their children's English learning?

\subsection{Data Analysis}

The data collected from this study were analyzed both quantitatively and qualitatively. The quantitative data were collected from the subjects' responses to the questionnaire on the Parents attitude toward early childhood English education in kindergartens. And to the qualitative data were the interviews' responses. The data was analyzed by IBM SPSS(20.0) to examine the descriptive statistics and independent sample t-test. Through the analysis, the researcher hoped to explore parental general opinion about the influence of early childhood English education in kindergarten.

\section{RESUlTS AND DisCUSSION}

1. What were Taiwanese parental general attitudes toward early childhood English education? Table 1 showed the top three general parental attitudes toward early childhood English education in kindergartens. 
Table1. Top three for General Parental Attitudes toward early childhood English education in kindergartens $(\mathrm{n}=200)$

\begin{tabular}{|l|l|l|l|}
\hline Item & Rank & Mean & SD \\
\hline The learning environment influence English development of children & 1 & 3.97 & 0.64 \\
\hline Infancy is the important periods for English learning and development & 2 & 3.96 & 0.57 \\
\hline Every English teacher of kindergartens should pass the GEPT test & 3 & 3.93 & 0.64 \\
\hline
\end{tabular}

Note: $S d=$ standard deviation, GEPT= the general English proficiency test

The results for Table 1 showed most parents agreed that The learning environment influence English development of children ( $\mathrm{M}=3.97 ; \mathrm{SD}=0.64)$, and most parents agreed that infancy is the important periods for English learning and development $(\mathrm{M}=3.96$; $\mathrm{SD}=0.57)$. The results also showed that every English teachers of kindergartens should pass the GEPT (the general English proficiency test) test $(\mathrm{M}=3.93 ; \mathrm{SD}=0.64)$. According to the results of first research question, we can realized most parents agreed that infancy is the important periods for English learning and development and the importance of English learning environment. Both PK and BK parents emphasized that English teachers should pass the general English proficiency test.

2. What were the significant differences in parental attitudes toward early childhood English learning between public and bilingual kindergartens?

Table2. Means, SD,t, and p for General Parental Perception of the Importance and Effection of Early Childhood English Education Between PK and BK $(n=200)$

\begin{tabular}{|c|c|c|c|c|c|c|}
\hline Item Description & $\begin{array}{l}\text { School } \\
\text { type }\end{array}$ & Mean & SD & $\mathrm{T}$ value & Sig & Rank \\
\hline \multirow{2}{*}{$\begin{array}{l}\text { 13. I choose the kindergarten for my children } \\
\text { depending on whether there was an English } \\
\text { course or not? }\end{array}$} & PK & 3.20 & .90 & \multirow[t]{2}{*}{$-3.06^{*}$} & \multirow[t]{2}{*}{.00} & \multirow[t]{2}{*}{1} \\
\hline & $\mathrm{BK}$ & 3.66 & .56 & & & \\
\hline \multirow{2}{*}{$\begin{array}{l}\text { 14. Public kindergartens should have basic } \\
\text { English course }\end{array}$} & PK & 3.96 & .61 & \multirow[t]{2}{*}{$2.51 *$} & \multirow[t]{2}{*}{.01} & \multirow[t]{2}{*}{2} \\
\hline & $\mathrm{BK}$ & 3.66 & .59 & & & \\
\hline \multirow{2}{*}{$\begin{array}{l}\text { 2. Learning English in early childhood is more } \\
\text { effective than in elementary schools }\end{array}$} & PK & 3.68 & .55 & \multirow[t]{2}{*}{$-2.17 *$} & \multirow[t]{2}{*}{.03} & \multirow[t]{2}{*}{3} \\
\hline & BK & 3.96 & .73 & & & \\
\hline \multirow{2}{*}{$\begin{array}{l}\text { 21. It's good for children to study one hour } \\
\text { English every day }\end{array}$} & PK & 3.56 & .76 & \multirow[t]{2}{*}{$2.06^{*}$} & \multirow[t]{2}{*}{.04} & \multirow[t]{2}{*}{4} \\
\hline & BK & 3.28 & .61 & & & \\
\hline \multirow{2}{*}{$\begin{array}{l}\text { 22. It's more effective for children to study in } \\
\text { whole day English course every day }\end{array}$} & PK & 3.28 & .83 & \multirow[t]{2}{*}{$-2.04 *$} & \multirow[t]{2}{*}{.04} & \multirow[t]{2}{*}{5} \\
\hline & $\mathrm{BK}$ & 3.60 & .73 & & & \\
\hline \multirow{2}{*}{$\begin{array}{l}\text { 32. I took my children to English cram school } \\
\text { before they entered the elementary school }\end{array}$} & PK & 3.12 & .80 & \multirow[t]{2}{*}{$2.04 *$} & \multirow[t]{2}{*}{.04} & \multirow[t]{2}{*}{5} \\
\hline & BK & 2.84 & .55 & & & \\
\hline
\end{tabular}

Note: $* P<0.05, P K=$ Public Kindergarten, $B K=$ Bilingual Kindergarten

The results showed that there were six significance different parental perceptions between public and bilingual kindergartens. The top three were BK parents chose the kindergarten were depending on whether there was an English course or not, but PK parents keep the different opinions $\left(\mathrm{t}=-3.06^{*}\right.$ at $\mathrm{p}=0.00)$. The second one was Public kindergartens should have basic English course $\left(\mathrm{t}=2.51^{*}\right.$ at $\mathrm{p}=0.01$ ). The third one was learning English in early childhood is more effective than in elementary schools $\left(\mathrm{t}=2.17^{*}\right.$ at $\left.\mathrm{p}=0.03\right)$. PK parents agreed children study one hour English every day is good for them $\left(\mathrm{t}=2.06^{*}\right.$ at $\left.\mathrm{p}=0.04\right)$. BK parents agreed It's more effective for children to study in whole day English course every day ( $\mathrm{t}=2.04 *$ at $\mathrm{p}=0.04)$. PK parents wanted to take children to English cram school before they entered the elementary school $(\mathrm{t}=2.04 *$ at $\mathrm{p}=0.04)$.

According to the results, BK parents chose the kindergarten for their children depended on whether there was an English course or not, but PK parents didn't. PK parents hoped public kindergarten could have basic English course and they agreed that learning English in early childhood is more effective than in elementary schools, but most BK parents didn't agree with that.

3. In parental opinions, what are the advantages and disadvantages for children to attend early childhood English education? 
Table3. Percentages for BK Parental Opinions about the Advantage of Early Childhood English Education $(n=10)$

\begin{tabular}{|l|l|l|l|}
\hline Category & $f$ & $\%$ & Rank \\
\hline Children can get good grades in English course in the future & 8 & 40 & 1 \\
\hline Children can get better jobs in the future. & 5 & 25 & 2 \\
\hline Increase young children's English ability & 4 & 20 & 3 \\
\hline To get the better development of children & 3 & 15 & 4 \\
\hline Total & 20 & 100 & \\
\hline
\end{tabular}

Note: $B K=$ Bilingual Kindergarten

Table4. Percentages for PK Parental Opinions about the Advantage of Early Childhood English Education $(n=10)$

\begin{tabular}{|l|l|l|l|}
\hline Category & $f$ & $\%$ & Rank \\
\hline Children can get good grades in English course in the future & 8 & 40 & 1 \\
\hline Increase young children's English ability & 6 & 30 & 2 \\
\hline Children can get better jobs in the future. & 4 & 20 & 3 \\
\hline To get the better development of children & 2 & 10 & 4 \\
\hline Total & 20 & 100 & \\
\hline
\end{tabular}

Note: $P K=$ Public Kindergarten

The results showed both PK and BK parents agreed that their children can get good grades in English course in the future and increase children's English ability after taking early childhood English education (40\%). Most BK parents believed their children can get better jobs in the future $(25 \%)$. Most PK parents believed their children can increase English ability after taking early childhood English education (30\%).

4. How do parents support their children learning English? The research question 4 was to explore how do parents support their children learning English.

(1). Why you choose to take your children to study in this public (bilingual) kindergarten?

Table5. Percentage of BK Parental Reasons for Chose Kindergartens $(n=10)$

\begin{tabular}{|l|l|l|l|}
\hline Category & $f$ & $\%$ & Rank \\
\hline Receive early childhood English education & 10 & 50 & 1 \\
\hline Increase competitiveness & 7 & 35 & 2 \\
\hline To fallow social norm & 3 & 15 & 3 \\
\hline Total & 20 & 100 & \\
\hline
\end{tabular}

Table6. Percentage of PK Parental Reasons for Chose Kindergartens $(n=10)$

\begin{tabular}{|l|l|l|l|}
\hline Category & $f$ & $\%$ & Rank \\
\hline No pressure & 5 & 50 & 1 \\
\hline Have fun & 5 & 50 & 2 \\
\hline Total & 10 & 100 & \\
\hline
\end{tabular}

Note: $P K=$ Public Kindergarten

The results showed most parents from BK parents chose bilingual kindergarten for their children to receive early childhood English education $(50 \%)$, but PK parents chose public kindergartens for their children to have fun and no pressure learning (50\%).

(2). In parental opinions, how early childhood English education affected children's Chinese learning?

Table7. Percentage of BK Parental Opinions for how Early Childhood English Education Affected Children's Chinese Learning $(n=10)$

\begin{tabular}{|l|l|l|l|}
\hline Category & $f$ & $\%$ & Rank \\
\hline English learning didn't affect Chinese learning & 6 & 60 & 1 \\
\hline Forgot Chinese words easily sometimes. & 4 & 40 & 2 \\
\hline Total & 10 & 100 & \\
\hline
\end{tabular}

Note: $B K=$ Bilingual Kindergarten 
Table8. Percentage of PK Parental Opinions for how Early Childhood English Education Affected Children's Chinese Learning $(n=10)$

\begin{tabular}{|l|l|l|l|}
\hline Category & $f$ & $\%$ & Rank \\
\hline English learning affect Chinese learning & 6 & 60 & 1 \\
\hline Forgot Chinese words easily & 2 & 20 & 2 \\
\hline Children don't like to write Chinese & 2 & 20 & 3 \\
\hline Total & 10 & 100 & \\
\hline
\end{tabular}

Note: $P K=$ Public Kindergarten

The results showed BK parents thought English learning didn't affect their children's Chinese learning $(60 \%)$, but they also agreed some children sometimes forgot Chinese words easily after taking early childhood English education (40\%). PK parents thought early childhood English education would affect their children's Chinese learning (60\%), and their thought young children would forget Chinese words easily (20\%) and children didn't like to write Chinese after taking early childhood English education (20\%).

(3). How do parents support their children's English learning?

Table9. Percentage for BK Parental Supports for Their Children Learning English $(n=10)$

\begin{tabular}{|l|l|l|l|}
\hline Category & $f$ & $\%$ & Rank \\
\hline Receive English courses in BK & 6 & 30 & 1 \\
\hline Listen to English Nursery Rhymes CDs & 6 & 30 & 1 \\
\hline Read English storybooks & 4 & 20 & 4 \\
\hline English cartoon & 2 & 10 & 5 \\
\hline English teaching DVD & 2 & 10 & 5 \\
\hline Total & 20 & 100 & \\
\hline
\end{tabular}

Note: $B K=$ Bilingual Kindergarten

Table10. Percentage for PK Parental Supports for Their Children Learning English ( $n=10)$

\begin{tabular}{|l|l|l|l|}
\hline Category & $f$ & $\%$ & Rank \\
\hline Nothing & 13 & 65 & 1 \\
\hline English cartoon & 5 & 25 & 2 \\
\hline Listen to English Nursery Rhymes CDs & 2 & 10 & 3 \\
\hline Total & 20 & 100 & \\
\hline
\end{tabular}

Note: $P K=$ Public Kindergarten

The results showed that parents from BK parents would provide English Nursery Rhymes CDs (30\%), took their children to Bilingual kindergarten to learn English (30\%), and read them English story books $(20 \%)$ to support their children's English learning. But parents from PK showed the opposite opinions that they do nothing (65\%) for their children's English learning, some of them have been provided TV program of English cartoon (25\%), and English songs to their children(10\%).

\section{CONClusion AND Suggestions}

The present study illustrated the proofed of previous studies, and pointed out that most parents agreed infancy is the important periods for English learning and development (Alhussein and Milian (2003), the importance of English learning environment, and qualified English teachers should pass the general English proficiency test. BK parents who chose the kindergarten for their children were depended on English course, they believed that their children would more clever and confidence than before after taking early childhood English education (Lao, 2004; Shannon \& Milian, 2002 \& Shin, 2000), but parents from PK chose the public kindergartens just hope their children could have fun learning and no pressure in kindergartens. However, PK parents still hoped public kindergartens should adding basic English course.

Moreover, In parental opinions, the advantages of early childhood English education were children can get good grades in English course and increased children's English abilities. Parents also believed their children can get better jobs in the future after taking early childhood English education (Lao, 2004; Liu \& Chien, 1998; Oladejo, 2006; Shang \& Ingebritson \& Tseng, 2007; Romero-gonzalez, 2008). For the disadvantage, BK parents thought early English childhood education didn't affect 
Chinese learning of their kids, but PK parents maintained the opposite opinions. PK parents emphasized children not only forgot Chinese words easily, but also didn't like to write Chinese after English class. However, PK parents didn't agreed their young children took early English education in kindergarten and took whole day English class.

In fact, because of the globalization in world technology, economy and education, bilingual education has upsurge in most kindergarten of China (Na, 2016). Early childhood English education has become an important issue. Furthermore, English is one of the important subject of schools curriculum in Taiwan. The results displayed that most Taiwanese parents of kindergarten strongly bolstered early childhood English education. They believed early childhood English education can provide boost opportunities for better career of their children in the future. The results of this study also highlighted the importance of better English learning condition for young children. The suggestion for further study was to explore school teachers' and government's general attitudes toward early childhood English education. To compare the results and suggested Taiwan government draw up the best English education policies and create a best language learning environment for young children.

\section{REFERENCES}

Alhussein, M. A., \& Milian, M. Saudi Parents' Attitudes Towards Their Children Learning English as a Second Language in the United States. http://faculty.ksu.edu.sa/default.aspx

Barbara A. C. (1996). Parental attitudes toward bilingualism in a local two-way Immersion program. The Bilingual Research Journal, 20(3), 383-410.

Butler, Y. G., \& Hakuta, K. (2004). Bilingualism and second language acquisition. The handbook of bilingualism, 114-144.

Butler, Y. (2004). What level of English proficiency do elementary school teachers need to attain to teach EFL? Case studies from Korea, Taiwan, and Japan.

TESOL Quarterly, 38(2), 245-278.

Cava, G. F. (1998). Parent attitudes, involvement, and satisfaction with two-way immersion programs.

Carolyn, T. \& Robert, L. (2010). Academic achievement through FLES: A case for Promoting greater access to foreign language study among young learners. The Modern Language Journal 94, 22 42.

Chang, H. L. (2004). A study of English learning condition of young kids: An example of an English only kindergarten in Taichung city. Retrieved December 19, 2005, from http://libserver2. nhu.edu.tw/ETD-db/ETD -search/ getfile?URN=etd-0705104-171427\&filename=etd-0705104171427.pdf

Chang, Y. F. (2008). Parents' attitudes toward the English education policy in Taiwan. Asia Pacific Education Review, 9(4), 423-435.

Chwen, C. T. \& Chia, H. H. (2010). The influence of the elementary students' early English learning experience on their English motivation and academic achievements. Journal of Educational Practice and Research, 23(2),95-124.

Cotton, K., \& Wikelund, K. R. (1989). Parent involvement in education. School Improvement Research Series, 6(3).

Eileen, H., Kathi, W. (2009). Learning language: listening and writing with diverse young children. Dimensions of Early Children, 37(2), 3-8.

Fauzia, F. (2016). Promoting Interaction among Students in the English Second Language (ESL) Learning Through Interactive Tasks. International Journal on Studies in English Language and Literature, 4, 100-105.

Feng, H. Y., Fan, J. J., \& Yang, H. Z. (2013). The relationship of learning motivation and achievement in EFL: Gender as an intermediated variable. Educational Research International, 2(2), 50-58.

Finney, S. A., Protopapas, A., \& Eimas, P. D. (1996). Attentional allocation to syllables in American English. Journal of Memory and Language, 35(6), 893-909.

Gardner, R. C. (1985). Social psychology and second language learning: The role of attitudes and motivation. Arnold.

Goh, C., \& Taib, Y. (2006). Metacognitive instruction in listening for young learners. EFT Journal, 60(3), 222-232.

Griva, E., \& Chouvarda, P. (2012). Developing Plurilingual Children: Parents' Beliefs and Attitudes towards English Language Learning and Multilingual Learning. World Journal of English 
Language, 2(3), 1.

Hui, F. S., Robert, I. \& Chien, L. T. (2007). Taiwanese parental perceptions toward English learning in bilingual kindergarten. I-Shou University Institutional Repository, Kaohsiung. Taiwan.

Jason, K. K. L. (2009). Teacher modeling: Its impact on an extensive reading Program. Reading in a Foreign Language, 21( 2), 93-118.

John, B., Stuart, Y., \& Denise, C. (2005). The effect of different types of corrective feedback on ESL student writing. Journal of Second Language Writing, 14, 191-205.

Lan, Y. C., Degotardi, S., \& Torr, J. (2011). Factors Related to the Home Teaching of English Language to Preschool aged Children: A Taiwanese Study. Asia-Pacific Journal of Research in Early Childhood Education, 5(2).

Lao, C. (2004). Parents' attitudes toward Chinese-English bilingual education and Chinese-language use. Bilingual Research Journal, 28(1), 99-121.

Larry, V. (1999). Facilitating second language listening comprehension: acquiring Successful strategies. Oxford University Press, ELT Journal, 53(3), 168-176.

Lee, J. S., \& Ginsburg, H. P. (2009). Early childhood teachers' misconceptions about mathematics education for young children in the United States. Australasian Journal of Early Childhood, 34(4), 37-46.

Lenneberg, E. H. (1969). On explaining language. Science, 164(3880), 635-43.

Lindholm-Leary, K. J., \& Borsato, G. (2002). Impact of two-way immersion on student's attitude toward school and college. Retrieved November 7, 2005, from http://repositories.cdlib.org/cgi/ viewcontent. . cgi $?$ article $=1073 \&$ context $=$ crede

Liu, K. C., \& Chien, C. Y. (1998). Project approach and parent involvement in Taiwan. Childhood Education, 74(4), 213-219.

Maisah. A. A., \& Madeline, M. (2003). Saudi parents' attitudes towards their children Learning English as a second language in the United States. Unpublished master's thesis.

Mariana, R.G. (2008). Parental motivations and attitudes toward a Spanishtwo-way

Immersion program in the Midwest. master's thesis, Iowa state university. Paper 11353. http://lib.dr.iastate.edu/etd/11353

Meadows M. (2009). A survey of kindergarten parents regarding their attitudes toward early intensive English-language instruction and its potential introduction at a small-scale, rural primary school. Bulletin of Nayoro City College 1(13). https://nayoro.repo.nii.ac.jp/?action=repository_uri\&item

Miao, L., \& Liying, C., \& John, R. K. (2012). Phonological awareness and listening among comprehension Chinese English- immersion students. International Education, 41(2), 46.

Mushi, S. L. (2001). Acquisition of Multiple Languages among Children of Immigrant Families: Parents' Role in the Home-School Language Pendulum.

Supporting Immigrant Children's Language Learning.

http://files.eric.ed.gov/fulltext/ED459622.pdf

Na, W. (2016). An Analysis of the Main Difficulties in Chinese Kindergarten Bilingual Education. International Journal on Studies in English Language and Literature, 4(3), 29-34.

Oladejo, J. (2006). Parents' attitudes towards bilingual education policy in Taiwan. Bilingual Research Journal, 30(1), 147-170.

Papadopoulos, I., \& Theologou, E., \& Theologou, M. (2016). Building Bridges with the Parables: Developing Bilingual Students' EFL Skills and Cultural Awareness within a Multimodal Learning Environment. International Journal on Studies in English Language and Literature, 4(2), 60-66.

Patricia, P. M. E. (2007) Latino public opinion survey of pre-kindergarten programs.

Alencia, Pérez \& Echeveste Public Relations.

Phyllis, W. (2005). Methods and materials for motivation and learner autonomy. Reflections on English Language Teaching, 5( 1), 93-122.

Romero-Gonzalez, M. (2008). Parental motivations and attitudes toward a Spanish two-way immersion program in the Midwest. ProQuest.

Rosenbush, M. H. (1987). Foreign Language Learning and Children: The Parental Role (ED 
289366).

Roopnarine, J. L., Shin, M., Donovan, B., \& Suppal, P. (2000). Sociocultural contexts of dramatic play: Implications for early education.

Sadighi, F., \& Zare, S. (2006). Is listening comprehension influenced by the background knowledge of the learners? A case study of Iranian EFL learners. The Linguistics Journal, 1(3), 110-126.

Saucedo, L. (1997). Parents' attitudes toward dual language immersion programs.

Retrieved October 30, 2005, from http://www.eric.ed.gov/ERICDocs/data/ericocs2/content storage_01/0000000b/80/25/98/e2.pdf

Shang, H. F., Ingebritson, R., \& Tseng, C. L. (2007). Taiwanese parental perceptions toward English learning in bilingual kindergarten. Applied English education: Trends and issues, 135-148.

Shannon, S. M., \& Milian, M. (2002). Parents choose dual language programs in Colorado: A survey. Bilingual Research Journal, 26(3), 681-696.

Shin (2000). Parent attitudes towards the principles of bilingual eucation and their children's participation in bilingual programs. Journal of In tercultural Studies, 21(1), 93-99.

Shu, C. H. (2010). Taiwan parents' beliefs and children's English learnng. master's thesis, Ming Chuan university.

Tavil, Z. (2009). Parental attitudes towards English education for kindergarten students in Turkey. Kastamonu Education Journal, 17(1), 331-340.

Tsai, C. H. (2001). Parents' attitudes toward English learning for their kindergarten children. Retrieved October 27, 2005, from http://datas.ncl.edu.tw/theabs/1/

Tsau, C. C. \& Hao, C. H., (2010). The Influence of the Elementary Students' Early English Learning Experience on their English Motivation and Academic Achievements. Journal of Educational Practice and Research, 23(2), 95-124, Dec. 2010.

Wu, K. H. (1998). The elimination of bilingual education in California. Tamkang Journal of Humanitarians and Social Sciences, 6, 197-198.

Young, R. L., \& Tran, M. T. (1999). Vietnamese parent attitudes toward bilingual education. Retrieved October 27, 2005, from http://brj.asu.edu/v2323/pdf/ar8.pdf\#search='Parent $\% 20$ attitudes\% 20toward $\% 20$ the $\% 20$ principles $\% 20$ of $\% 20$ bilingual $\% 20$ education $\% 20$ and $\% 20$ their $\%$ 20children $\% \mathrm{E} 2 \% 80 \% 99 \mathrm{~s} \% 20$

Yi, Y. L. (2009). Parents' perspectives and young children's Chinese language communication in symbolic play: cases of bilinqual and half-day English classes. master's thesis, Chaoy-Yan university.

Young, A. S. (1994). Motivational State and Process within the Socio-Linguistic Context. Birmingham: Aston University.

Yuan, H. L. (2009). A Study of EFL listening difficulties and strategies of senior high School students. Unpublished master's theses, National Taiwan Science and Technology University, Taipei, Taiwan.

Yuh, F. C. (2008). Parents' attitudes toward the English education policy in Taiwan. Asia Pacific Education Review 9(4), 423-435.

Yuko, L. (2008). The perceptions of Japanese students toward academic English reading: implications for effective ESL reading strategies. Multicultural Education, 46-50.

$\mathrm{Xu}$, F. (2008). Listening comprehension in EFL teaching. US-China Foreign Language,6(1). ISSN1539-8080, USA.

Z.muge, T. (2009). Parental attitudes toward English education for kindergarten students in Turkey. Kastamonu Education Journal, 17(1) 331-340. 